\title{
ÎNTEMEIEREA ETICĂ A SPECTACOLULUI DE TEATRU
}

\author{
Sabin Sabados
}

DOI 10.46522/CT.2021.02.06

\author{
Abstract \\ The Etical Foundation of Theater Performance
}

The way we interpret artistic creations - and especially theatrical ones - is about value judgments based on what the eye holds and the spirit embodies. If we accept the Kantian view that we have a world of things and a world of people - which will shed light on the relationship between aesthetics and ethics, between the work of art and human behaviour, between beauty and attitudes - we can accept that the supreme value that governs us is the moral law, understood as a necessary and universal principle. In our work we will try to show that, on the one hand, the stage creation and its reception are based on rules and norms not arbitrary, but deeply rooted in the human being, on the other hand, that the theatrical work (more precisely, the theatre performance) tends to free itself from any constraints, seeking solutions "beyond good and evil", not in order to invalidate their validity, but to make a return, through knowledge and interpretation, a return to the bosom of ethics.

\section{Keywords:}

aesthetics, ethics, performing arts, Kant, judgment ao taste

ândirea umană are capacitatea de a distinge, în mod obiectiv și subiectiv, între bine și rău, între adevăr și fals și, nu în ultimul rând, între frumusețea virtuții 
și urâțenia viciului: „Prin urmare, se pare că virtutea este sănătate, frumusețe, buna dispoziție a sufletului, iar viciul înseamnă boală, urâțenie și slăbiciune “1. În plan valoric, deosebirile pe care Platon le propune își dovedesc utilitatea odată ce sunt general acceptate și înscrise în ceea ce numim simțul comun. Adică din clipa în care sunt admise ca atare de cei mai mulți dintre noi, tocmai pentru că avem de-a face cu ceva ce ține de evidență. Aprecierea și valorizarea operei de artă devin posibile abia atunci când judecățile subiective și cele obiective sunt întemeiate pe un mod de interpretare rațională și, respectiv, pe o interpretare intuitivă. Oricât de rudimentare sau de elementare ne-ar putea apărea la prima vedere cele două procese, nu putem să nu recunoaștem că ne prevalăm de ele ori de câte ori ne întâlnim la teatru, interogându-ne cu privire la ceea ce reprezintă virtutea, în contextul și în relație cu plăcerea estetică. Și, odată cu aceasta, vom putea exclama, pe urmele lui Heidegger, că arta (implicit teatrul) este forma în care se afirmă ființa ființei.

\section{1. Împreună cu opera}

În lumina a ceea ce reprezintă plăcerea estetică - dar și în prelungirea intuiției, care se dovedește a fi un mijloc al cunoașterii și al conturării unor certitudini interioare în absența rațiunii -, trebuie să ținem seama, pe de o parte, de dimensiunea subiectivă a gândirii (a întregului proces cognitiv), pe de alta, de dimensiunea obiectivă a lucrurilor, spre care ne îndreptăm interesul și care ne îndreptățește să apreciem existența unei logici a faptelor și a lucrurilor din viața noastră: „Așadar, cei care își rotesc privirile asupra multitudinii de lucruri frumoase, dar nu percep frumosul absolut și nici nu pot să meargă împreună cu cei care ar vrea să-i conducă spre o asemenea contemplare [cum este, de altfel, cazul celor care creează arta spectacolului de teatru - n.m.], care văd multitudinea de acțiuni drepte, dar nu văd dreptatea însăși, și așa mai departe, despre aceia vom spune că au opinii cu

1. Platon, Republica, traducere de Dumitru Vanghelis, București, Editura Antet XX Press, [2014], p. 140. 
privire la orice, dar nu cunosc nimic în ceea ce privește lucrurile despre care opinează“" ${ }^{\text {. }}$ Nu puțini sunt cei care, folosindu-se doar de bunul simț și de bunul gust, atunci când au de-a face cu o creație scenică, văd strălucirea frumuseții acesteia, dar nu văd universalitatea frumosului însuși.

Urmând logica socratică, remarcată de Platon, putem distinge între opiniile pe care ni le formăm și cunoștințele la care ajungem, atunci când suntem implicați efectiv în actul creației, cum este cazul spectacolului de teatru. Practic, se poate spune că, atunci când schimbăm opinii într-un ,ecosistem artistic“, avem tendința să spunem mai multe despre noi decât despre opera creată, pe când, atunci când căutăm răspunsuri împreună cu opera, dobândim cunoștințe specifice, atenția fiindu-ne mutată spre „obiectul artistic/estetic“. Însă ceea ce ne interesează cu privire la această „ordine logică“ a creației artistice (ca și a interpretării scenice, dacă ne interesăm de spectacolul de teatru) este să înțelegem experiența încercată și, mai important, maniera în care reușim o interiorizare (o încorporare - v. infra) a acestei experiențe pe care arta teatrului ne-o propune.

Dacă din perspectiva analizei fenomenului artistic admitem atât opiniile subiective (judecățile de gust), cât și cunoștințele în sine, cel puțin cele care sunt măcar în parte obiectiv fundamentate (judecățile estetice), atunci devine imperativă dobândirea unui tip de înțelegere a creației și a interpretării prin apelul la o judecată etică. Este vorba de o înțelegere care încorporează opiniile și cunoștințele într-o experiență interioară unică, urmare acordului care se stabilește între frumos și adevărul pe care „obiectul“ artistic îl transmite.

Complexitatea arhitecturii cognitive, a minții umane, se dovedește greu de egalat atunci când aceasta se pune, în mod voit, în relație cu artele spectacolului de teatru. Pentru a ajunge la o deosebire și mai evidentă între bine și rău, între adevăr și fals, între frumos și urât, dar și între categoriile esteticii proprii domeniului de care suntem interesați, vom considera că orice demers analitic poate fi constituit în trei etape, înlănțuite și gradual parcurse: începem cu „opinia subiectivă“, pe

2. Ibidem, p. 180. 
care o trecem prin filtrul „cunoașterii științifice“, în încercarea fundamentării estetice a acesteia și cu scopul de a ajunge la o „înțelegere profundă“ a creației, adică la întemeierea ei etică. Sub raportul cunoștințelor, dacă luăm în considerare faptul că artistul este unul dintre puținii capabili să exprime estetic un adevăr etic, putem spune că arta sa este mai aproape de adevăr decât orice altă creație umană. Sub raportul înțelegerii, vom spune că numai artistul care înțelege și își asumă un astfel de adevăr ca fiind imperativ poate să îl arate corect sau să îl sugereze celorlalți în cel mai bun mod cu putință. Iată de ce discursul estetic trebuie să aibă mereu în vedere posibilitatea de a interacționa cu arta căreia îi acordă interes, prin prisma mai largă a unei capacității superioare cunoașterii raționale, cum este cea care îmbogățește creația cu datele virtuții, cu alte cuvinte, cunoașterea artistică: „De bună seamă că există o virtute [n. a.] a artei, dar nu și una a înțelepciunii, care este ea însăși o virtute. Pe de altă parte, când e vorba de artă, este mai bine să greșești de bunăvoie decât involuntar; când e vorba de înțelepciune, lucrurile stau invers, ca și în cazul virtuților morale“3. Altfel spus, în artă, în general, și în artele spectacolului de teatru, în particular, atâta timp cât „greșeala“ - adică renunțarea la canon - este una intenționată, se pare că nu sunt încălcate imperativele etice.

Intenția artistică, oricare ar fi ea, devine un scut de protecție împotriva neajunsurilor (sau a disfuncțiilor) vieții și a influențelor nedorite (și, până la urmă, ne protejează de un posibil „rău“ ontologic), cărora trebuie să le facem față în întreaga noastră existență. Sub aspectul receptării estetice, dar și al interpretării etice, putem vorbi de o adevărată înțelepciune estetică, pe care o vom înțelege ca asumare etică a actului creator, cu alte cuvinte, ca interes pentru tot ceea ce reprezintă binele. Constituită estetic și fundamentată pe principiile eticii, înțelepciunea estetică mai poate fi tradusă ca acord între voința artistului și necesitățile absolute ale ființei.

3. Platon, Dialoguri socratice. Lahes, Lysis, Charmides, Hippias minor, Euthyphron, Apărarea lui Socrate, Criton, traducere, studii introductive și note de Francisca Băltăceanu et. al., selecție și prefață de Gheorghe Pașcalău, ilustrații de Mihail Coșulețu, București, Editura Humanitas, 2015, pp. 177-178. 
Pentru că artistul este interesat să stabilească o relație eliberată de prejudecăți cu scena, acesta își pune întrebări cu privire la modul în care creația teatrală va avea un efect asupra celor cărora li se adresează și, prin aceasta, dacă va genera o schimbare în lumea în care trăiește. Și aceasta, în condițiile în care nu se poate îndepărta de pozițiile unei etici (asumate sau anume sfidate) și urmare a faptului că orice creator se gândește la creația sa, încercând să-și traducă (să-și teoretizeze) demersul artistic ca dialog cu ceilalți. Trebuie spus că transgresivitatea actorului, precum și manifestările personajului întrupat, în raport cu lumea în care a fost aruncat (cea a reprezentației, adică a cronotopului scenic) pot să producă schimbări cu efect de scurtă sau de lungă durată. Pe de altă parte, trebuie să acceptăm că nu întotdeauna celui care se alătură spectacolului de teatru - cu scopul de a-și răspunde unor întrebări sau chiar de a se descoperi pe sine - îi este asigurată pășirea pe traseul cunoașterii și al elevării spirituale.

Implicațiile etice ale spectacolului de teatru au rolul de a ne călăuzi spre universalitatea frumosului. În accepție platoniciană, asemenea virtuții și adevărului, frumosul (tocmai prin universalitatea sa) trimite atât la lumea „sensibilă“, cât și la cea „suprasensibilă“. Așadar, putem considera că, într-un spectacol de teatru, este vorba, în egală măsură, despre adevăr și despre frumos. În această ordine de idei, ne amintim cuvintele lui Titu Maiorescu: „[...] cea dintâi și cea mai mare diferență între adevăr și frumos este că adevărul cuprinde numai idei, pe când frumosul cuprinde idei manifestate în materia sensibilă“44. Orice înțelegere a dimensiunii etice a artelor spectacolului devine dificilă (sau chiar imposibilă) în condițiile în care creatorii de teatru nu acordă importanța cuvenită rolului pe care intenția voit manifestată îl joacă în procesul de creație artistică și în cel de interpretare estetică. În artele spectacolului de teatru, vom recunoaște, de fiecare dată, o mișcare de du-te-vino între spațiul unei etici aflată în stadiul de potențialitate și cel al manifestării acesteia

4. Titu Maiorescu, Critice. 1866-1907, ediție completă, vol. I, București, Editura Minerva, 1915, p. 13. 
prin normele și cutumele sociale, culturale, ideologice etc. Într-o astfel de accepțiune, putem înțelege spectacolul de teatru ca permanentă actualizare a potențialului etic, la nivelul formei și al conținutului operei reprezentate.

\section{Despre arta voit înfăptuită}

Omul nu este o simplă ființă ,știutoare“, capabilă de procese cognitive, de raționalizări, în cel mai fericit caz, clar formulate. Iar, în teatru, acest lucru este cu atât mai evident, în măsura în care, pe scenă, creația se supune unui ansamblu de condiționări și de trăiri, evidente fiind sentimentele, talentul, cunoașterea, spontaneitatea, inspirația și multe altele. În plus, creația se împlinește prin dinamica expresiei scenice, prin imagini aflate într-o continuă mișcare, adică prin viul și vitalitatea operei.

Este de la sine înțeles că, într-o activitate artistică, avem de-a face cu mai multe tipuri de acțiuni. Unele sunt declanșate și conduse artistic în mod voluntar și conștient, altele, chiar dacă nu se supun unui efort al rațiunii - prin așanumitele mecanisme automatizate ale gândirii -, continuă să fie voit infăptuite. Procesul de creație scenică presupune un set de reguli și de deprinderi specifice artei sale. Însă, dacă în cazul literaturii, „travaliul creator“ este dat de dificultatea transferului de semnificații din planul gesturilor și al mimicii în cel al expresiei lingvistice ${ }^{5}$, în cazul reprezentației scenice, acesta vizează o limitare a codurilor lingvistice, cu scopul de a elibera corpul și a-l lăsa să se exprime fără constrângeri, prin intermediul elementelor paralingvistice: intonație, gesturi, mimică. Așa cum remarca și Didier Anzieu, dacă, în primul caz (consemnat de Jakobson), codul poetic reprezintă o suprapunere a axei paradigmatice peste cea sintagmatică, în cel de-al doilea caz (de această dată, preluarea fiind de la Umberto Eco) codul teatral reclamă o inversă suprapunere a celor două axe ${ }^{6}$. Pe măsură ce deprinderile jocului scenic sunt

5. Cf. Didier Anzieu, Psihanaliza travaliului creator, traducere din limba franceză și prefață de Bogdan Ghiu, București, Editura Trei, 2004, p. 202.

6. Ibidem. 
exersate, ele vor facilita manifestarea talentului, sau chiar îl pot suplini. Deprinderile actorului se diferențiază de ceea ce apreciem în mod obișnuit ca talent, urmare a faptului că sunt dobândite pe parcursul vieții, prin educație, prin experiență artistică, prin imitație etc. Actorul poate învăța deprinderile scenice, însă talentul este înnăscut. Dacă apelăm la o interpretare ontologică de tipul celei practicate, în secolul al XVIII-lea, de Jean-François Marmontel, putem spune că talentul actorului se recunoaște în forma creației, în gesturile și mimica acestuia, în timp ce deprinderile vor consolida conținutul și vor face vizibil sensul operei ${ }^{7}$. De regulă, actorul își amintește modul de învățare a acestor deprinderi, dar și dificultățile, atenția și efortul la care s-a supus. Numai prin exersare continuă, deprinderile pot să devină componente autonome ale creației artistice.

Consolidate prin exercițiu scenic, aceste competențe conștient elaborate - îi vor permite actorului să-și încarneze personajul fără a întârzia prea mult pe detaliile interpretării și pe ceea ce acestea vor semnifica. Deprinderile sunt formate astfel încât să fie întotdeauna intenționate, chiar și atunci când nu presupun un control conștient permanent. Din perspectivă estetică vom spune că, în astfel de situații, avem de-a face cu o automatizare a intenției artistice. Or, reversul constă în aceea că, ajungându-se în timp la o fixare a deprinderilor, acestea vor putea fi modificate cu dificultate, $\mathrm{cu}$ alte cuvinte, vor pretinde efortul actorului de a ieși din zona manierismului. Putem vorbi de deprinderi și în cazul receptării operei artistice (de orice tip ar fi aceasta), ceea ce aduce în discuție ansamblul capacităților senzorial-perceptive ale spectatorului. Odată formate, deprinderile legate, pe de o parte, de receptarea creației, pe de alta, de interpretarea acesteia, vor permite recunoașterea frumosului, a adevărului, a sensului și a semnificației operei reprezentate, cu o subsumare implicită a principiilor etice pe care spectacolul este clădit.

7. Cf. Étienne Souriau, „Du génie en philosophie“, în: Revue philosophique, vol. CLXV, nr. 2, apr.-iun. 1975, p. 134. 


\section{De la principii la judecata sensibilă}

Preocupat de modulîn care ajungem să cunoaștem rațional ceva, Immanuel Kant considera că omul este beneficiarul a trei facultăți: facultatea de a gândi (liber), facultatea de a acționa (moral) și facultatea de a simți și judeca (etic și estetic). Răspunsul kantian la întrebarea „care este sursa cunoașterii?"“ este unul triadic: rațiunea teoretică; experiența practică; judecata subiectivă și/sau obiectivă. Iar din cele trei critici kantiene se desprind: cunoașterea înțelegătoare (prin rațiune); voință ca temelie etică a cunoașterii (prin acțiune); sentimentul estetic al judecății (prin simțire). Între cele trei critici există o tranziție firească. Immanuel Kant și-a conceput sistemul filosofic la sfârșitul secolului al XVIIIlea, într-o perioadă marcată de o profundă criză morală, o

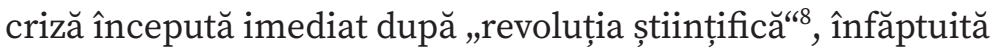
în relație cu ideea de Bine absolut, spre care tinde totul în natură, în social, în cultură și în artă.

Orice teorie etică operează cu principii universal valabile. Dar ce este un principiu? Având un caracter polisemic, un principiu (cu originea în noțiunea de arkhè a presocraticilor) reprezintă o convingere imperativă care funcționează ca un reper general valabil, aplicabil în toate activitățile pe care le întreprindem și în toate domeniile, inclusiv în cel al practicii filosofice, al cercetării științifice sau al creației artistice. De regulă, el derivă din relația nemărginită pe care o avem cu realitatea, o realitate pe care încercăm să o cunoaștem și să o înțelegem printr-un adevăr prim al lucrurilor sau al ideilor. La Platon, principiul - ca primă cauză a ceea ce este - trimite la Unul, care este identic cu binele (și cu Zeul), fără a fi supus comandamentelor rațiunii umane. El este (la) originea

8. Odată cu „revoluția științifică“ (secolele XV-XVII) și momentul de glorie coperniciană, s-au produs o serie de descoperiri și transformări în toate domeniile, punându-se astfel bazele științelor moderne, urmare a revenirii la concepția filosofică mecanicistă cu privire la existența lumii (cunoașterea este posibilă numai prin determinarea relației cauză-efect). În această perioadă, începe să prindă contur tot mai mult utilitarismul ca fundament al moralei (V. Jeremy Bentham și mai apoi John Stuart Mill), în detrimentul eticii. 
lucrurilor. Dacă vorbim despre conștiință ca principiu prim al existenței, tot astfel vom putea vorbi despre frumos ca principiu de bază al esteticii. În etică, principiul se rezumă la un set de norme deontologice (de exemplu, „Să nu furi!“). Având un sens obiectiv (ontologic sau metafizic) și unul subiectiv (logic sau emoțional), principiul este, cel mai adesea, asociat cu cauza primă a lucrurilor, așa cum, de altfel, a fost sugerat de Aristotel. Ori de câte ori reușim să identificăm prezența unor caracteristici dominante în sfera moralității, atunci ele devin principii în funcție de care vom avea drepturi, obligații, responsabilități, sensibilități etc.

Dacă ne întoarcem privirea spre secolul al XVIII-lea, vom constata că, drept urmare a diminuării autorității teologice, morala epocii s-a constituit pe ceea ce era apreciat ca util pentru societate, omului cerându-i-se să se apropie de natură, de sine și de ceilalți, pentru a lăsa în urmă temerile în raport cu Cerul și cu tradiția religioasă. Morala devine, astfel, o producție a sufletului și nu a minții: „Ori de câte ori un obiect are tendința de a produce plăcere celui care îl posedă sau, cu alte cuvinte, este cauza propriu-zisă a plăcerii, este cert că va provoca plăcere spectatorului printr-o relație de simpatie delicată cu posesorul. Cele mai multe opere de artă sunt considerate frumoase în funcție de utilitatea lor și chiar și multe creații ale naturii își derivă frumusețea din această sursă. Eleganța și frumusețea, în cele mai multe cazuri, nu sunt calități absolute, ci calități relative, și nu ne atrag decât prin tendința lor de a conduce la un final agreabil“"

Într-o accepție subiectivistă (anti-realistă și, totodată, sfidătoare la adresa metafizicii), proprie filosofiei lui David Hume, am putea spune că distincția dintre bine și rău este o chestiune ce ține de moralitatea persoanei. În fapt, afirmă Hume, binele și răul se amestecă, iar principiul nu este nici binevoitor, nici răuvoitor. Tot astfel, gândirea nu va putea niciodată să fie egala senzației sau a sentimentelor (într-un cuvânt, a impresiilor, care sunt produse de experiența vie și

9. David Hume, A Treatise of Human Nature, reprinted from the original edition in three volume, and edited, with an analytical index, by L.A. Selby-Bigge, Oxford, Clarendon Press, 1896, pp. 576-577. 
imediată). Întrucât spectacolul de teatru nu ni se înfățișează ca fenomen pur, rațiunea - restrângându-și aria de competență la constatarea existenței unui fapt - va face loc judecății sensibile (idee pe care o vom putea vedea strecurată, mai târziu, și în scrierile lui Rousseau). Faptul artistic, asemenea celui cotidian, va putea fi consemnat ca virtuos sau vicios doar prin apelul la o instanță morală, care, la rândul ei, se bazează pe sentimente. Într-o astfel de logică, sentimentul moral al insului este primul semn în funcție de care vom recunoaște un adevăr obiectiv. Or, acest lucru ne îndreptățește să credem, oarecum în contracurentul gândirii lui Hume, că subiectivității umane îi este alăturată o obiectivitate aflată in statu nascendi.

Dar nu doar etica este legată de utilitatea acțiunilor, ci și estetica. În acest sens, am putea crede că frumosul nu este „conservat“ în obiectul creației, ci se naște în privirea receptorului, dând coerență vizibilului, observație care 1-a îndreptățit pe Hume să propună mai degrabă o analiză a judecății de gust, conform căreia echilibrul formelor ne-ar da starea de bine și de împlinire, în timp ce formele fragile ne-ar conduce la suferință. Or, chiar dacă experiența subiectivă a artei funcționează pe baza gustului, a emoției și a simpatiei cu opera evaluată, unde își dovedește și utilitatea estetică, nu înseamnă, oare, că aceasta prezintă aceleași date și în cazul abordării etice a frumosului și a artei?

\section{Intenția actului creator}

Kant este cât se poate de realist în privința principiilor morale, motiv pentru care și-a orientat atenția, cel puțin în primele două critici (Critica rațiunii pure și Critica rațiunii practice) mai degrabă spre facultățile cognitive ale omului decât spre cele afective. Pe când, am văzut, în viziunea filosofului David Hume, preocupat de metoda științelor naturii, lucrurile stăteau exact invers. Procedând astfel, Kant a reușit să evite implicațiile etice ivite pe fondul interpretărilor deterministe sau a celor mecaniciste, predominante în epocă. În substanța lor, cele două viziuni filosofice ne spun că totul are o cauză. Dacă acest lucru este adevărat și dacă totul este determinat de o cauză sau de o succesiune de cauze anterioare, atunci cu 
greu mai putem vorbi despre responsabilitatea morală a unui individ sau despre un aport subiectiv al creatorului în realizarea operei sale. În această logică, artistul nu poate fi făcut responsabil pentru creația sa. Pentru că, în această ordine de idei, arta nu este altceva decât un produs secundar, un efect sau un derivat al unei cauze străine de practica artistică. Și pentru că, în definitiv, nu știm care este cauza pentru care omul creează artă. În fine, fiindcă distingem între cauzalitatea și intenționalitatea unui proces de creație artistică, suntem tentați să pledăm în favoarea unei poziții care ne spune că arta este atât scopul, cât și mijlocul prin care Binele se înfăptuiește ca orice manifestare a frumosului.

Pentru actor, actul scenic este un rezultat final al procesului său de creație, însă, pentru spectator, acesta reprezintă o premisă, un punct de plecare învestit cu un scop în sine. Oricât de tentantă pare a fi, aprecierea artei teatrale ca produs al unei cauzalității rămâne greu de demonstrat; ea este considerată, mai degrabă, mijloc prin care, antrenând perspectiva subiectivă, vom putea obține plăcere ori satisfacție estetică. Pe de altă parte, din punct de vedere obiectiv, putem spune că orice creație artistică veritabilă are un scop în sine. Un scop care urmează a fi descoperit și redescoperit și care, în funcție de natura relațiilor stabilite cu opera, dar și în contextul apariției și manifestării acesteia, poate fi considerată un bun necesar pentru noi. Creația în sine (teatrală sau aparținând oricărui alt gen) nu dobândește calitatea de operă artistică în absența judecății acesteia (și chiar a judecății de gust), a noțiunilor, a conceptelor și a teoriilor care o întâmpină sau pe care le promovează. Pentru ca un fapt să treacă din lumea cotidiană în cea a spectacolului de artă, e necesară o dezbatere care își poate găsi locul în sfera categoriilor mentale și a unor cunoștințe legate de ceea ce este în sine arta.

Potrivit lui Kant, orice ființă rațională (în stare de a aduna judecăți) este capabilă să facă o „distincție obiectivă“ (și, în consecință, etică) între bine și rău, între virtute și viciu, motiv pentru care sistemul moral al unei colectivități este (sau ar trebui să fie) mai mult decât un construct subiectiv, cu o plajă largă de înțelegere a lucrurilor și la care ajungem cu ușurință la un consens. Această distincție se realizează ca urmare a 
voinței umane liber manifestate, pe fondul unui dat preexistent, adică al unei structuri „apriorice“ ce funcționează în chip „transcendental“. Cele două concepte - ,aprioric“ și „transcendental“ - devin principii fundamentale de înțelegere a sistemului filosofic propus de filosoful german. Aplicată artei spectacolului de teatru, o atare înțelegere etică se întemeiază la fel de bine pe concepte (pe rațiune) și pe sentimente (pe afectivitate). Așadar, trebuie să analizăm care este sensul presupus de Immanuel Kant, ori de câte ori acesta îl folosește. Conceptul „de «transcendent» se referă la formele apriorice ale cunoașterii, care o iau înaintea experienței și o condiționează; adică sunt acele forme care se află în afara lumii reale, percepute de simțurile omenești. Conceptul «a priori» trimite la o cunoaștere anterioară și independentă de orice experiență; gândirea «a priori» se sprijină doar pe rațiune; în opoziție, formele «a posteriori» ale cunoașterii sunt condiționate de experiență și se ivesc în urma unor experiențe de care răspund simțurile ${ }^{\text {"“10 }}$.

Voința este cea care imprimă în conștiința artistului intenționalitatea, făcând posibilă manifestarea energiei motrice a forței creatoare. Dacă intenționalitatea descrie orientarea artistică, dimensiunea energetică (sau, altfel, energia care) se reflectă din realitate implică faptul că efectul voinței artistice „se exprimă“ în conștiință sub forma unor încordări și tensionări care se leagă de traducerea ei în formă estetică. Sub impulsul voinței, conștiința umană devine generatoare și urmăritoare de scopuri artistice și estetice. Ea devine, în fapt, o conștiință deschisă. Voința artistică intră întotdeauna pe terenul unei conștiințe influențate de o sumă de factori emoționali. Odată ce s-a sedimentat corespunzător, această influență va fi resimțită ca roditoare pe tărâmul „memoriei afective“. Iar conștiința celui care alege să stabilească o relație cu arta pretinde în mod imperativ ca piatra de temelie a acestei relații să fie de natură etică.

Immanuel Kant abordează etica folosind aceeași cheie „rațională“ de înțelegere a lucrurilor ca în cazul cercetării metafizice. Adică printr-o abordare critică a condițiilor care nu o fac doar posibilă, ci și accesibilă gândirii - o gândire care

10. Sabin Sabados, Estetica și misterul frumosului, București, Editura Eikon, 2019, p. 60. 
se află în noi și care, totodată, ne traversează în momentele de cumpănă ale interpretării. Apelând la un același tip de gândire interpretativă, am putea spune că, așa cum spiritul reprezintă condiția existenței ființei gânditoare - o ființă care, fără a putea fi exprimată, poate fi intuită într-o manieră sensibilă -, etica reprezintă condiția de manifestare a ființei morale.

În cercetarea sursei cunoașterii și a modului în care un atare proces are $1 \mathrm{loc}^{11}$, ceea ce îl interesează cu precădere pe filosoful german este: 1) să găsească acele structuri apriorice ale gândirii care fac posibilă înțelegerea; principiul aprioric kantian este un principiu subiectiv care precedă însuși procesul cunoașterii raționale (gândirea care se gândește cum gândește; înainte ca orice să fie, trebuie să preexiste un timp și un spațiu în care acel ceva să poată ființa - în acest exemplu, timpul și spațiul sunt structuri apriorice); 2) să demonstreze că structurile cu care gândirea operează nu sunt pur subiective (cum se întâmplă în cazul ideilor, formelor și categoriilor raționale), ci au un corelat obiectiv; 3) să arate că orice fel de „datorie morală“ a omului trebuie să fie în concordanță cu o etică atotcuprinzătoare.

Întrebarea care apare în acest punct este dacă structurile subiective ale gândirii, în speță cele care obligă la respectul față de legea morală, au sau nu au un fundament obiectiv. Altfel spus, există legi morale obiective? Răspunsul kantian este un da categoric în favoarea obligațiilor morale obiective, în sensul unei delimitări între bine și rău. O distincție care să nu se bazeze doar pe ce știe, ce simte, ce crede, ce dorește sau ce-i place subiectului, adică pe o ,jumătate de adevăr“, ci și pe un adevăr care să fie obiectiv și, prin extensie, cuprinzător, adică unificator al virtuților și al fericirii, formator al binelui suprem.

\section{Transpunerea în real: între subiectiv și obiectiv}

În mai toate domeniile în care își desfășoară activitatea, cu atât mai mult în sfera artelor, categoriile cu care gândirea operează par a fi pur subiective. Cel puțin în măsura în care

11. V. Immanuel Kant, Critica rațiunii pure, traducere de Nicolae Bagdasar și Elena Moisuc, ediția a III-a îngrijită de Ilie Pârvu, București, 
acestea sunt considerate creații umane. În cazul eticii, însă, Immanuel Kant remarcă modul în care aceste categorii devin imperative, pentru că, de fiecare dată, ele presupun în prealabil un corelat obiectiv, nepărtinitor. Pasul suplimentar pe care demonstrația kantiană îl propune ține de pretenția legitimă pe care etica o poate ridica în raport cu toate celelalte domenii. Acesta este probabil și unul dintre motivele pentru care avem deontologia care ne obligă la respectarea prevederilor normative (și, ca urmare, etice) în toate activitățile pe care omul le întreprinde, cum sunt, ca exemplu, profesiile din domeniile educațional, juridic, medical etc.

$\mathrm{Cu}$ riscul asumat de a continua polemica pe marginea acestei chestiuni, vom considera că domeniul artistic nu face excepție în această privință, în consecință, ne orientăm atenția spre o etică estetică și/sau artistică a artei teatrului. Experiența estetică, dobândită pe fondul contemplării unei opere artistice frumoase, reprezintă un tip aparte de experiență. Aceasta pentru că insul care o trăiește încearcă o cuprindere (adică o recunoaștere) în sine a ceva ce se află în afara sa. Nefiind imitaţia unui fapt preexistent (sau al vieții noastre senzoriale), creația teatrală conduce spectatorul la o încorporare a sensului operei, în prezența, dar și în absența „obiectului creației“. Ducând dincolo de sala de spectacol judecăți de gust, emoții, trăiri și interogații de care nu era conștient înainte de începerea reprezentației, spectatorul confirmă calitatea teatrului de producător al unei realități, ceea ce amintește de teoria estetică a lui Ernst Cassirer: „Dacă de la începuturile timpului, cele două mari principii, al imitației și al transformării realității, și-au disputat dreptul de a fi considerate adevăratele expresii ale esenței activității artistice, o soluționare a conflictului pare posibilă doar prin înlocuirea acestora cu un al treilea principiu, al producerii realității [s. m.]. Căci arta nu este altceva decât unul dintre mijloacele prin care omul își poate apropria [s. m.] realitatea. “12

Editura Univers Enciclopedic Gold, 2009, passim.

12. Apud Rémi Mermet, „L'objet de l'art: Cassirer et Fiedler“, in: Recherches germaniques, nr. 51, 2021, consultat la 26 ianuarie 2022. URL: http://journals.openedition.org/rg/7583; DOI: https:// doi.org/10.4000/rg.7583. 
Starea de contemplare se desprinde de experiența individuală a fiecărui spectator și face posibilă fuziunea cu elementele semnificative ale creației, prinse în forma operei artistice. Iar această formă devine semnificativă și durabilă doar în actul manifestării ei, adică, în cazul teatrului, în timpul reprezentației, în urma unui acord (tacit „semnat“) cu publicul. Într-un cuvânt, nu realitatea acțiunii scenice va persista, ci forma realului care se clădește în spectator. În sens metaforic, putem înțelege întâlnirea privitorului cu obiectul privit (cu scena) ca un soi de contaminare (i.e. de analogie cognitiv-emoțională) cu ceea ce răzbate din actul teatral și, mai apoi, de catharsis, prin declanșarea crizei existențiale a tuturor celor implicați, ceea ce ne întoarce, din nou, la viziunea lui Artaud cu privire la ciumă, la contagiune, la spasmul vieții. Înțeleasă astfel, experiența estetică oferă creatorilor de teatru, chiar dacă doar pentru o perioadă relativ scurtă de timp, posibilitatea unei transpunerii in real a elementelor ontologice ale operei scenice (adică prin transformarea lor în elemente cu însemnătate ontică). Prin imersiune în spațiul și în timpul „,istoriei“ reprezentate, actorul și spectatorul depășesc limitele propriei condiții existențiale, aventurându-se pe un teren cu topografie necunoscută. Chiar o suferință trăită de personajul prezent pe scenă face posibilă bucuria întâlnirii cu altul, prin împărtășirea sentimentelor și, conform lui Cassirer, prin valorizarea funcției pur intuitive a realității.

Judecata estetică a artei, pusă în corelație cu o judecată etică, se obiectivează și devine mai mult decât o judecată de gust (sau o apreciere subiectivă), pentru că implică atât un act reflexiv empiric (care trimite la un șir lung de evenimente pe care spectatorul le aduce vrând-nevrând în actualitate), cât și unul care solicită intuiția și se dezice de „învățăturile“ rațiunii. Între sensibil și inteligibil se stabilesc legături strânse. Spre exemplu, în primă instanță, judecăm mai degrabă din punct de vedere etic decât estetic un spectacol de teatru, atunci când facem următoarea afirmație: „Actul scenic este fals!“. Prin această afirmație, fie legitimăm faptul că, în realitate, ceea ce creația scenică livrează nu convinge, pentru că nu este veridic, fie considerăm, intuitiv, că lucrarea rămâne neîmplinită din perspectivă estetică. Iată cum, prin această 
judecată, avem de-a face atât cu o interpretarea empirică a actului scenic, care privește sensul și semnificația lucrurilor, cât și cu o cunoaștere apriorică a ceea ce înseamnă „fals“ în contextul creației. La acest din urmă principiu, aprioric, ajungem ca urmare a conștientizării implicațiilor eticii în relația dintre actor și spectator, aceasta fiind singura în măsură să ne ghideze judecata, pentru a separa ceea ce este adevărat de ceea ce este fals.

Tradusă în termeni estetici, judecata etică ne spune că „expresia scenică“ (sau „mișcarea expresivă“) nu convinge sub aspectul universalității la care spectacolul de teatru tinde, asemenea oricărei creații artistice, și pe care, pe de altă parte, etica o pretinde în mod imperativ. Din perspectivă estetică, actului scenic îi poate fi atribuită o valoare artistică subiectivă și nicidecum una pur obiectivă, caz în care interpretarea ar întâmpina reale obstacole. Pentru a recunoaște valoarea obiectivă a creației scenice, este nevoie să apelăm, așa cum am văzut, la o judecată etică și nicidecum estetică. Iar pentru ca gestul scenic să redevină „expresie vizuală“, e nevoie ca interpretarea să revină la „darul“ intuiției, validând importanța cunoașterii estetice. Dacă, din perspectiva eticii, vom privi actul artistic în fenomenalitatea lui, prin restrângerea interesului la vizibilitatea pură a lucrurilor și prin luarea în stăpânire a lumii reprezentate, pe planul esteticii, lucrurile se vor desfășura pe dos: întâmplarea scenică se va transforma în „întâmplat" al propriului eu, mobilizând trăiri și sentimente dintre cele mai neașteptate. Dacă actorul va miza pe reperele expresiei artistice, spectatorul va apela la impresia estetică.

Mișcarea de recunoaștere - reflectând raportul tensionat dintre formă și lipsa formei, dintre ființă și devenire - ne va întoarce, din nou și din nou, la „mișcarea expresivă“ pe care arta teatrului își clădește existența, eliberându-se de condiționările contingentului. Or, să nu uităm că, dacă teatrul își are originea în expresivitatea sa scenică, subiectivându-și propriul discurs, evoluția sa privește lumea vizibilă, obiectivă, supusă interpretării, evaluării și valorizării, într-un cuvânt, depinde de proba eticii și a moralei timpului său. 


\section{Bibliografie}

Platon, Republica, traducere de Dumitru Vanghelis, București, Editura Antet XX Press, [2014].

Platon, Dialoguri socratice. Lahes, Lysis, Charmides, Hippias minor, Euthyphron, Apărarea lui Socrate Criton, traducere, studii introductive și note de Francisca Băltăceanu et. al., selecție și prefață de Gheorghe Pașcalău, ilustrații de Mihail Coșulețu, București, Editura Humanitas, 2015.

MAIORESCU, Titu, Critice. 1866-1907, ediție completă, vol. I, București, Editura Minerva, 1915.

ANZIEU, Didier, Psihanaliza travaliului creator, traducere din limba franceză și prefață de Bogdan Ghiu, București, Editura Trei, 2004.

SOURIAU, Étienne, „Du génie en philosophie“, în: Revue philosophique, vol. CLXV, nr. 2, apr.-iun. 1975, pp. 129-146.

Hume, David, A Treatise of Human Nature, reprinted from the original edition in three volume, and edited, with an analytical index, by L.A. Selby-Bigge, Oxford, Clarendon Press, 1896.

SABADos, Sabin, Estetica și misterul frumosului, București, Editura Eikon, 2019.

KANT, Immanuel, Critica rațiunii pure, traducere de Nicolae Bagdasar și Elena Moisuc, ediția a III-a, îngrijită de Ilie Pârvu, București, Editura Univers Enciclopedic Gold, 2009.

MERMET, Rémi , „L'objet de l'art: Cassirer et Fiedler“, in: Recherches germaniques, nr. 51, 2021, consultat la 26 ianuarie 2022. URL: http://journals.openedition.org/rg/7583; DOI: https://doi. org/10.4000/rg.7583. 